\title{
PROGRAM KONTRA WACANA TERORISME: SEBUAH USULAN ANTROPOLOGIS SEBAGAI ALTERNATIF DERADIKALISASI DI INDONESIA
}

\author{
Al Chaidar 1, Herdi Sahrasad 2, Iskandar Zulkarnaen 3, Fauzi A Rahman 4 , \\ Muntasir Abdul Kadir 5, \\ ${ }^{1}$ University of Malikussaleh, Aceh. Kandidat PhD Universitas Indonesia \\ 2 Universitas Paramadina, Jakarta \\ 3 Program Studi Ilmu Politik, Universitas Malikussaleh, Aceh \\ ${ }^{4}$ Program Sosiologi, Universitas Malikussaleh, Aceh \\ 5 Program Studi Ilmu Politik, Universitas Malikussaleh, Aceh \\ correspondence: alchaidar@unimal.ac.id
}

\begin{abstract}
Program counter-discourse (kontra wacana) adalah program yang berusaha menciptakan "a way of thinking that opposes an institutionalized discourse". Selama ini wacana kaum fundamentalis, kaum radikal hinga kelompokkelompok teroris sudah terlembaga sedemikian rupa di Indonesia melalui proses yang panjang dalam sejarah sosial politik negeri ini. Teka-teki yang muncul atas motif apakah yang mendasari makin maraknya kaum profesional yang berkecukupan tergiur untuk menjadi tentara Negara Islam Irak dan Suriah (NIIS) atau yang lebih dikenal dengan ISIS (Islamic State of Iraq and Syria) belum juga terpecahkan secara komprehensif. Hingga saat ini, sudah sekitar 518 warga negara Indonesia diduga bergabung dengan ISIS dan menurut catatan Sidney Jones dari Institute for Policy Analysis of Conflict (IPAC), sudah lebih dari 800 warga negara Indonesia yang sudah berangkat dan bergabung dengan gerakan "teroris" tersebut di Suriah. Oleh karena itu, perlu membangun kontra wacana sebagai benteng untuk membendung upaya "cuci otak" yang dilakukan oleh pihak-pihak yang tidak bertanggung jawab. Program ini tentu saja tidak akan berjalan tanpa dukungan dari berbagai pihak terkait, terutama pihak-pihak yang paham dengan permasalahan ini. Padahal, di sisi lain, upaya dan program nyata untuk memerangi terorisme yang bersifat straight-forward dan sistematis seharusnya terus digalakkan dan terlembaga. Harapannya, program kontra wacana ini dapat mereduksi dan menghantam ideologi-ideologi yang menyimpang yang selama ini dianut oleh gerakan-gerakan sosial politik keagamaan.
\end{abstract}

Keywords: Kontra Wacana, Terorisme, Deradikalisasi 


\section{A. Pendahuluan}

The Intercept (8 Juli 2015) mengungkapkan dua pilot Indonesia (Ridwan Agustin alias Ridwan Ahmad al-Indunesiy dan kapten Tommy Hendratno alias Tommy Abu Al Fatih Hendratno) yang pernah menjadi aparat keamanan negara dan kemudian menjadi pilot sebuah maskapai multinasional, kini bergabung dengan ISIS. Banyak yang kemudian khawatir atas pilihan hidup yang dijalani dua profesional di usianya yang masih sangat produktif ini. Tidak sedikit pula yang mempertanyakan tentang motif keduanya ikut bergabung menjadi tentara ISIS, membela sesuatu yang mungkin dianggap sangat ideal di suatu tempat nun jauh di sana di luar tanah Indonesia. Bahkan kalangan politisi di dunia Barat cemas dengan rekam jejak mereka yang sebelumnya pernah bergabung dengan kesatuan keamanan negara yang sangat disegani di kawasan Asia Tenggara.

Sebelumnya, seorang anggota polisi aktif di Jambi, Syahputra (alias Abu Azzayn al Indunesiy) meninggalkan anak istrinya dan berangkat melalui Medan ke Suriah untuk berjihad melawan apa yang mereka persepsikan sebagai "thoghut" (musuh) yaitu rezim Bashir Al Asad. Statusnya sebagai anggota kepolisian negara ini dengan gaji yang berkecukupan tentu mengundang tanda-tanya besar: ada apa di balik semua ini? Tindakannya meninggalkan anak istri untuk berjihad ke sana, menceburkan diri ke dalam kancah perang, tentulah bukan sebuah keputusan rasional biasa. Ada sesuatu yang tak teridentifikasi dari realitas sosial yang problematik ini.

Semua kekhawatiran dan kecemasan berbagai kalangan ini sangat rasional. Kaum profesional dengan basis status sosial ekonomi kelas menengah dan dengan latar-belakang keluarga yang relatif sakinah ini tentunya mengharapkan jawaban nyata atas tanya yang membingungkan. Tindakan Syahputra menceraikan istrinya dan pergi ke tanah asing berperang tentunya tidak bisa dijelaskan dari perspektif psiko-sosial generik. Pasti ada alasan-alasan teologis atau bahkan eskatologis dari tindakan yang tidak biasa ini.

Dari perspektif modern, banyak analisis tentang daya tarik finansial yang ditawarkan ISIS kepada sesiapa yang berkenan bergabung dengan bala tentara multi nasionalnya. Peluang ini disambut baik oleh banyak kalangan yang, menurut perhitungan berbagai ahli, berasal dari kaum marjinal yang berusaha mencari 
penghidupan ekonomi yang lebih layak. Bahkan ada juga yang menyebutkan tentang motif seksual yang melatari keinginan sebagian kecil warga Indonesia untuk berpartisipasi di dalam perang atau konflik di Suriah dan Irak tersebut. Ketika maraknya pencekalan terhadap orang-orang yang diduga hendak berangkat ke Suriah di berbagai bandara di Indonesia dan Malaysia sejak tahun 2013 hingga 2014, analisis economic interest sebagai motif sangat mendominasi penjelasan tentang latar-belakang kaum marjinal ini. Hampir tidak ada satu analisis pun yang mengaitkannya dengan kesadaran ideologis para aktor pendukung ISIS tersebut. Bahkan Daniel Bell (1960) dan Francis Fukuyama (1996) sangat yakin bahwa ideologi telah mati dan tak bisa memengaruhi kebangkitan dunia Timur. Akan tetapi, analisis kepentingan ekonomi, atau motif material apa pun, menjadi tidak mampu menjelaskan mengapa kaum profesional ikut terlibat dalam konflik yang sangat mengerikan bagi banyak kalangan.

Dibutuhkan satu penjelasan yang lain yang secara akademis bisa dipertanggungjawabkan untuk memberikan jawaban atas fenomena yang sangat mengejutkan dunia ini. Secara antropologis, D’Andrade dan Strauss (1992) pernah mengajukan motif kultural yang bersifat ideologis atas fenomena maraknya perlawanan bersenjata dan konflik komunal di berbagai belahan dunia. Gupta dan Ferguson (1992) mencoba menjabarkan motif cultural model tersebut sebagai " $a$ sense of loss territorial root" dimana nilai-nilai nasionalisme dan patriotisme sudah mulai pudar atau sedang terjadinya "an erosion of the cultural distinctiveness of place" yang kemudian menghasilkan sebuah produk sampingan dari globalisasi yang disebut sebagai "deterritorialization of identity" dimana identitas tidak lagi dilekatkan pada tempat dimana seseorang dilahirkan atau dibesarkan dalam suatu periode formative age yang sangat menentukan. Identitas yang berdasarkan lokalitas tergantikan oleh apa yang sejak lama dikenal sebagai ideologi. Ideologi Islam telah menjadi pilihan bagi dua pilot dan satu polisi dari Indonesia yang tentunya telah terasuh di bawah ideologi Pancasila dan digaji oleh hasil pajak warga negara yang hidup di alam demokrasi.

Ridwan Agustin dan Tommy Hendratno serta Syahputra yang telah mengalami indoktrinasi ideologi sekuler ini kemudian menggantikannya dengan ideologi yang baru dipeluknya. Ke manakah nasionalisme dan patriotisme yang 
sempat diajarkan oleh negara ini? Nasionalisme dan patriotisme adalah ideologi yang berbasis tempat dan akan mudah hilang ketika kenangan tentang tempat itu semakin memudar di tengah kosmopolitnya dunia yang sekuler dan materialistis ini. Edward Said (1979: 18) menjelaskan situasi ideologi yang menembus batasbatas nasionalitas dan lokalitas lainnya sebagai "a generalized condition of homelessness". Inilah yang mungkin bisa kita sebut sebagai ideologi transnasional keagamaan yang selama ini menyebar semenjak berakhirnya perang dingin antara Blok Kapitalis dan Blok Komunis/Sosialis. Kedua blok ideologis ini, oleh kalangan gerakan Islam transnasional dianggap telah menyebarkan polusi mental dan mengancam kesucian agama. Konsep "pollution and purity" (Louis Dumont, 1970 [1966]) inilah yang kemudian dikembangkan secara akademis untuk menjelaskan mengapa pilihan ideologis menjadi rasional di atas pilihan-pilihan material dan ekonomis lainnya.

Analisis ideologis menjadi penting ketika penjelasan-penjelasan motif ekonomi, sosio-psikologis dan politik menjadi lumpuh di hadapan realitas sosial yang problematik ini (Talal Asad, 1979; Louis Althusser, 1977; George Marcus, 1986; Maurice Bloch, 1983 dan 1986). Renato Rosaldo (1988) memperlihatkan bagaimana ideologi tidak lagi mengenal batas-batas tempat dan merasuki ke berbagai kalangan yang disebutnya sebagai "people without culture" ini. Ideologi jihadisme yang selama ini dianggap bertanggung jawab atau setidaknya berada di belakang semua perlawanan berdarah dengan segala kesemrawutan sosiologisnya, setidaknya bisa memberikan penjelasan tentang fenomena kembalinya ideologi dalam analisis ilmu-ilmu sosial dan humaniora.

Kecenderungan semakin materialnya analisis sosial atas berbagai gejala munculnya gerakan-gerakan perlawanan dan konflik keagamaan haruslah diimbangi dengan analisis kultural yang memadai. Kembalinya ideologi bagi banyak kalangan dari berbagai latar belakang sosial ekonomi menunjukkan bahwa faktor non-material jauh lebih kuat dalam memengaruhi motif seseorang atau sekelompok orang dalam melakukan tindakan-tindakan perlawanan. Geertz (1973: 220) menyebutkan bahwa ideologi adalah bagian dari sistem budaya yang memetakan realitas-realitas sosial yang problematik dan menjadi matriks bagi terciptanya kesadaran sosial. Ideologi inilah yang mendasari Ridwan Agustin, Tommy 
Hendratno, Syahputra dan juga Heri Kustiyanto meninggalkan segala kecukupan duniawi dan membuang semua spirit in the material world yang pernah mereka anut sebelumnya. Mereka menuju ke sebuah harapan baru yang masih belum jelas secara material, namun sangat jelas secara ideologis: janji surga bagi yang syahid dan syafaat bagi keluarga batih dan kerabatnya.

Matriks kesadaran sosial ini dibangun oleh kalangan yang merasakan adanya luka moral (moral torment) yang disebabkan oleh serangan ideologi lain (Joel Robbins, 2004). Kesadaran sosial keterjajahan inilah yang kemudian menggerakkan mereka untuk menuntut balas atas luka moral yang masih menganga tersebut. Kesadaran sosial ini bukan dibangun atas dasar nasionalisme atau etnisitas, melainkan berdiri secara transnasional sebagai sebuah kesadaran baru yang disebut oleh Michael Francis Laffan (2003) sebagai Islamic nationhood. Di sinilah konsep ummah dibangun sebagai sebuah kesadaran sosial yang memengaruhi berbagai orang untuk berpartisipasi di dalam pembentukan sebuah negara Islam di Suriah dan Irak (ISIS).

Konsep Laffan (2003) tentang spirit bela negara dalam komunitas Islam ini begitu membahana dan setidaknya menjadi ketertarikan politik bagi gerakangerakan lainnya. Ideologi Islamic nationhood ini mempengaruhi banyak gerakangerakan radikal dan teroris di berbagai belahan dunia. Mujahidin Indonesia Timur (MIT) di Poso segera menyatakan sumpah setia (bai'at) kepada khalifah Al Baghdadi yang memimpin ISIS (2013), juga Boko Haram di Negeria tersirap dengan peragaan kekerasaan yang diperlihatkan ISIS (2014). Beberapa faksi mujahidin di Suriah, Afghanistan, Palestina, Lebanon, dan wilayah-wilayah lainnya menyatakan solidaritasnya untuk mendukung dan bergabung dengan gerakan yang dianggap sebagai representasi alam bawah sadar mereka untuk menggentarkan musuhmusuh agama yang telah menorehkan moral torment terhadap umat Islam selama berabad-abad.

Bahkan belum lama ini Fakhruddin bin Kasem alias Din Robot, mantan panglima sagoe Gerakan Aceh Merdeka (GAM) di Julok, Aceh Timur (Serambi Indonesia, 7/9/2015) menyatakan hasratnya untuk bergabung dengan ISIS. Meskipun hasrat politik yang tersendat ini dianggap banyak pihak sebagai langkah sensasional saja, setidaknya realitas sosial problematik ini dipengaruhi oleh 
merebaknya ideologi kebangsaan Islam yang diembuskan oleh ISIS. Bayangan akan sebuah tamkin (kekuasaan riil de facto) negara Islam yang de facto menjadi daya tarik utama bagi banyak gerakan pemberontakan. Al Qaeda pun kewalahan menghadapi berbagai serangan ISIS di basis-basis yang sudah mereka rebut sebelumnya di Suriah, Irak dan Afghanistan. Al Qaeda kalah cepat dalam mewujudkan idealitas arkaik yang sangat diharapkan banyak kalangan radikal dan fundamentalis Islam, yaitu keinginan untuk memiliki sebuah tamkin (negara) yang definitif. Posisi tanzhim (gerakan, kekuasaan de jure) Al Qaeda perlahan-lahan mulai tergeser oleh ISIS yang rajin mempertontonkan kebiadaban dan kekerasan sebagai kabar gembira dan peringatan untuk memuaskan dendam keterjajahan lama di bawah sistem kapitalisme dan neo-liberalisme Barat.

Motif kultural atau motif ideologis inilah yang mungkin sedang disemai oleh kaum profesional yang selama ini merasakan hidupnya yang berkecukupan tersebut belumlah cukup secara teologis dan eskatologis. Ada kekeringan spiritual yang akut di sana. Ada tujuan-tujuan akhirat yang mendasari tindakan mereka dalam bergabung dengan ISIS nun jauh di Suriah sana. Negeri yang jauh itu tidak dipandang akan memberikan kesejahteraan material bagi pemuasan nafsu badaniah, melainkan perang itu adalah peluang bagi mereka untuk menggapai hasrat teologis dan eskatologis mereka untuk menuju ke surga dan bercengkerama dengan para bidadari yang senantiasa perawan. Ini adalah sebuah keyakinan, sebuah ideologi yang tidak bisa ditukar dengan imbalan material sebesar apa pun. Ideologi millenarian inilah yang selama ini dicari, dan ketika ditemukan, maka kelezatan duniawi apa pun akan ditinggalkan dengan serta-merta.

\section{B. Pembahasan}

\section{Tipologi Wahabisme}

Fenomena merebaknya benturan mazhab antara Wahabi dan kalangan tradisional Islam telah membuat banyak orang bertanya-tanya tentang apa itu Wahabi, bagaimana sejarahnya dan apa bahaya dari mewabahnya aliran atau sekte yang dianggap radikal ini? GNMT berusaha menjawab pertanyaan tersebut secara sekilas untuk mendudukkan perkara yang sebenarnya agar tidak terjadi kesalahpahaman yang bisa berakibat fatal. Agama adalah unsur kebudayaan yang paling sulit diubah (Achmad Fedyani Saifuddin, 2012) dan pengaruhnya paling sulit 
dikendalikan (Houston Smith, 1976). Benturan peradaban atau clash of civilization (Samuel Huntington, 1978) terjadi karena agama. Benturan di dalam peradaban atau clash within civilization juga terjadi karena agama (Hans Dieter Senghaas, 2002). Paham keagamaan yang dituduh paling banyak menyumbangkan konflik, perang, terorisme dan kekerasan komunal adalah, salah satunya, paham Wahabisme. Maka kita perlu memahami Wahabi secara sosiologis, teologis, sejarah, politik dan antropologis. Tulisan ini tidak akan bisa menjelaskan semua itu hanya dalam uraian ringkas beberapa frasa kalimat saja. Tulisan ini lebih merupakan executive summary untuk kalangan awam atau semacam policy brief untuk yang super sibuk, yang bahan-bahannya dikumpulkan dari kalangan "Wahabi” sendiri yang menjadi subyek penelitian saya selama ini.

Pada dasarnya, Islam itu hanya satu, namun karena perkembangan sejarah, politik, ekonomi dan budaya, maka Islam ikut berkembang berdasarkan wilayah persebarannya. Geopolitik Islam kontemporer sekarang ini menjadi tidak lagi satu, monolitik dan integral seperti pada masa nabi Muhammad SAW. Kini terdapat banyak kelompok, pecahan, aliran, sekte dan mazhab yang cukup beragam. Perpecahan pertama adalah pembelahan ideologis yang sangat besar antara (1) Sunni, dan (2) Syiah. Sunni dan Syiah ini juga terpecah dalam berbagai kelompokkelompok atau sekte dan mazhab yang semuanya mengklaim dirinya yang paling benar. Tidak akan ada kemunculan kelompok baru tanpa klaim kebenaran. Klaim kebenaran inilah yang menyebabkan terjadinya perpecahan di dalam Islam.

Sunni adalah mazhab besar kaum pengikut ahlus sunnah wal jamaah yang sangat menghormati Nabi, berserta seluruh sahabat dan juga keluarganya. Muhammadiyah dan Nahdlatul Ulama (NU), Persis, Al Washliyah, Al Irsyad, Perti, Masyumi, DI atau NII, JI, MMI, JAT, JAS adalah termasuk ke dalam kelompok Sunni. Syiah adalah mazhab yang selektif dalam mengakui sahabat Nabi dan juga keluarganya, mereka hanya mengagumi Ali ibn Abi Thalib r.a dan anaknya yang kedua, Husen, dari 11 anak Ali r.a. Karena minoritas, kelompok Syiah di Indonesia hanya sedikit saja dan organisasinya pun (beserta pecahannya) tak begitu tampil ke permukaan. Antara Sunni dan Syiah pun sering terjadi bentrokan yang melibatkan kekerasan berdarah. 
Di kalangan Sunni perpecahan juga banyak terjadi dan membentuk banyak kelompok keagamaan, mazhab, sekte dan aliran yang sangat beragam. Wahabi adalah salah sebuah mazhab dalam kalangan Sunni. Baru baru ini di Madura ada sebuah lagu yang berjudul "Wahabi" yang sangat lugas menggambarkan apa itu aliran yang dianggap radikal oleh banyak kalangan. Lagu itu menggambarkan Wahabi tidak suka maulid nabi, tidak mau tahlilan, tidak setuju ziarah kubur, tidak mengakui qunut, dan menganggap semua orang Islam di luar kelompoknya sebagai sesat, bid'ah atau bahkan kafir. Stigma buruk sering disematkan kepada Wahabi dan label ekstrim sering ditujukan kepada kelompok ini. Dalam banyak hal lagu ini ada benarnya, namun tidak semua Wahabi berperilaku demikian.

Menurut Syaikh Muhammad bin Jamil Zainu (1986), Wahabi adalah paham keagamaan yang dianut kalangan yang tidak suka kepada adat-istiadat dan kebiasaan yang menyimpang yang mengharap kekuatan leluhur, melanggar tradisi adat, tidak mau ikut maulidan Nabi, tidak percaya kepada sunan, wali dan keramatkeramatnya, anti tahyul, khurafat dan bid'ah. Kata Wahabi adalah nisbat kepada Muhammad bin Abdul Wahab, padahal Abdul Wahab adalah nama ayahnya yang tidak pernah menulis satu kitab fiqh pun. Nisbat kepada nama Abdul Wahab ini dibuat oleh kalangan ilmuwan Barat yang biasanya mengambil nama belakang untuk katalogisasi kepustakaan.

Wahabi digagas oleh Syaikh Muhammad bin Abdul Wahab (1703-1792), seorang reformis (mujaddid) Islam dari Najd, Arab Saudi yang muncul di tengah galaunya ummat Islam yang lama terasuh di bawah empat mazhab statis (Syafii, Maliki, Hambali dan Hanafi). Ia adalah seorang mufti dari Daulah Suudiyah, cikal bakal Kerajaan Arab Saudi yang kita kenal sekarang. Muhammad bin Abdul Wahab menyeru kaumnya kepada tauhid, hanya berdoa memohon kepada Allah tanpa perantara, tidak mengagungkan para wali dan orang alim atau ulama atau orangorang sholeh sebagai orang yang lebih istimewa dan menolak menyembah kuburan. Wahabi menganut prinsip egaliter dalam beribadah. Muhammad bin Abdul Wahab ini dianggap sebagai pembuat mazhab kelima setelah mazhab Syafi'i, Hambali, Hanafi dan Maliki. Muhammad bin Abdul Wahab ini banyak menulis kitab yang isinya sejalan dengan pemikiran-pemikiran Ibnu Taymiyyah, Ibnu al-Qayyim,dan Ahmad bin Hanbal. Karena dipengaruhi oleh pemikiran dari Ahmad bin Hanbal, 
Wahabiisme ini agak mirip dengan mazhab Hambali. Pemikiran Wahabi ini kemudian dikembangkan oleh Bin Baz, Utsaymin, Syek Ahmad Khan, Jamaluddin Al Afghani, Rashid Ridha, Muhammad Abduh, HOS Tjokroaminoto, SM Kartosoewirjo. Kemudian pada periode pasca kolonialisme, ideologi Wahabi dikembangkan lebih sistematis lagi oleh Sayyid Qutb, Muhammad Qutb, Hasan Al Banna, Abul A'la Al Maududi, Yusuf Qardhawi, dan Nashiruddin Al Albani. Kemudian pada masa revolusi di Afghanistan ideologi ini dikemas rapi dalam buku-buku karya Abdullah Azzam, Osama Bin Laden, Ayman Al Zawahiry, hingga ke periode konflik Iraq dan Suriah oleh Abu Mushab As Shuri.

Wahabi tidak monolitik, artinya kelompok ini juga terpecah ke dalam beberapa varian yang satu sama lainnya tidak bersahabat, terkadang saling bermusuhan atau bahkan juga bisa menjurus ke konflik berdarah. Wahabi sebenarnya adalah istilah yang generik untuk menyebut atau merujuk kepada kelompok Salafi. Namun karena kaum tradisional Islam pun mengklaim dirinya sebagai Salafi (yang melaksanakan tradisi Salafussholeh), maka label Wahabi dipilih agar mudah membedakannya secara teologis dengan kelompok-kelompok yang bukan Wahabi. Terminologi Wahabi pun dipakai sebagai euphemisme karena ada kelompok tertentu yang sangat sensitif dengan nama Salafi. Secara antropologis, terdapat setidaknya tiga tipologi Wahabisme di Indonesia yang bisa saya amati. Pertama, Wahabi Shururi atau Wahabi yang dianggap anti maulid, anti azan dua kali, anti tahlil, anti ziarah kubur dan anti jihad dan sering menganggap masyarakat yang melawan pemerintah sebagai bughot (pemberontak). Kedua, Wahabi Jihadi, yatu kelompok yang lebih fokus pada jihad dan berusaha melawan setiap kebijakan pemerintah, juga memiliki sikap penolakan yang sama dengan kelompok pertama. Wahabi Jihadi di Indonesia pernah muncul dengan nama Darul Islam (DI) di Jawa Barat tahun 1949 [dengan tokohnya Sekarmadji Maridjan Kartosoewirjo], Jawa Tengah tahun 1950 [Amir Fatah Widjaja Kusuma], Sulawesi Selatan tahun 1951 [Kahar Muzakkar], Kalimantan Selatan tahun1952 [Ibnu Hajar] dan Aceh tahun 1953 [Daud Beureu'eh], kemudian Jamaah Islamiyyah (JI) tahun 1992 hingga tahun 2010 yang dituduhkan kepada Ustadz Abdullah Sungkar dan Abubakar Ba'asyir, Dr Azhari, Noordin Mat Top, Amrozi, Imam Samudra, Ali Ghufron dan Ali Imron. Terakhir, kelompok Wahabi Jihadi ini muncul dalam bentuk Tanzhim Al Qaeda 
Serambi Mekkah (TQSM) dan banyak aktivisnya yang tertangkap setelah terbongkarnya kegiatan i'dad (persiapan/latihan perang) di Bukit Jalin, Aceh Besar pada 2010. Kelompok Wahabi Jihadi ini kini lebih kalem dan memilih jalur dakwah bil hikmah dalam kegiatan kesehariannya. Ketiga, Wahabi Takfiri yang suka menuduh orang lain di luar kelompoknya sebagai pelaku bid'ah atau malah kafir. Kelompok ini ada di Aceh saat ini dan masih setia dengan bai'at-nya untuk mendukung Negara Islam Irak dan Syam (NIIS) atau lebih dikenal dengan ISIS.

Di internal kalangan Wahabi ini sendiri juga terjadi saling tuding dan saling tuduh sesat menyesatkan. Kalangan Wahabi Shururi sering menuduh Wahabi Jihadi sebagai bughot. Wahabi Jihadi lebih banyak pasif dan tak bereaksi secara sosial dan politik. Wahabi Jihadi lebih mengutamakan ibadah-ibadah mahdhoh (ritual) dan menghindari friksi dengan pihak manapun, aktif dalam berbagai acara penyadaran tauhid ummat. Sementara kalangan Wahabi Takfiri sangat hiperaktif dalam dakwahnya dan menuduh banyak kalangan Jihadi sebagai bid'ah, sesat atau kafir terhadap banyak kelompok karena tidak mau menerima khilafah Al-Baghdadi di Suriah dan Iraq. Melalui media sosial kelompok Wahabi Takfiri ini mengumbar seruan-seruannya yang berisik dan penuh ancaman dan tudingan sembari memperlihatkan sikap intolerannya secara asertif.

Di tengah kiprah Wahabi dalam konflik komunal di Peristiwa Cumbok di Aceh (1946), Ambon (1999) Poso (2001) dan lain-lain tempat, juga ada kiprah Wahabi dalam kekerasan politik di Sulawesi Selatan serta kiprah Wahabi dalam terorisme yang diperankan oleh Jamaah islamiyyah, Darul Islam, dan lain-lain sebagainya sejak tahun 2000 hingga tahun 2014. Inilah yang kemudian membuat Wahabi menjadi paragon of ugly yang sulit untuk dibantah. Seharusnya Wahabi lebih tampil sebagai paragon of beauty dan mengharumkan agama Islam di mata dunia. Kejadian-kejadian kekerasan di Iraq dan Suriah dimana ISIS memperlihatkan kekejamannya yang mengerikan telah membuat Wahabi sebagai pihak yang dianggap bertanggungjawab secara teologis atas kekerasan dan kebiadaban ini.

Padahal, banyak sekali jasa Wahabi dalam membela kaum tertindas di muka bumi ini. Bantuan kepada pengungsi Rohingya justru datang dari Arab Saudi yang dianggap sebagai negara Wahabi. Kita haruslah menilai Wahabi ini secara lebih adil sebelum menjatuhkan stigma atau label radikal, ekstrimis dan teroris kepada 
semuanya yang berasal dari mainstream Wahabi. Padahal ada Wahabi yang anti jihad, yang anti pemberontakan, dan juga Wahabi yang bisa menerima ziarah kubur, tahlil, maulidan dan juga masih bersedia datang ke kenduri-kenduri untuk menyantap hidangan.

Di tengah banyaknya tudingan terhadap kalangan Wahabi yang dianggap telah mempermalukan agama Islam, namun harus diakui bahwa ada banyak jasa Wahabi dalam membela kaum tertindas, khususnya yang beragam Islam. Hampir dapat dipastikan kebanyakan yang dibela oleh Wahabi adalah ummat Islam tanpa membedakan sekte dan mazhab. Bantuan kemanusiaan yang diberikan kaum Wahabi menyebar ke seluruh dunia dalam bentuk filantropi zakat, sedekah, qurban dan pembangunan masjid serta lembaga pendidikan.

\section{Peluang bagi Program Kontra Wacana Terorisme}

Gerakan politik Islam radikal di Indonesia sedang mengalami kerumitan, semacam situasi disorientasi, dislokasi dan diposisi yang kemungkinan akan mengalami titik-balik (turning point) lahirnya pemimpin baru yang berbeda atau lebih baik pasca Ustadz Abdusshomad atau yang lebih dikenal dengan nama Ustadz Abubakar Ba'asyir (ABB). ABB adalah pemimpin kharismatik terakhir dari kalangan jihadis Indonesia yang mengalami gonjang-ganjing perpecahan dalam kurun sejarah pergolakan yang panjang. Perpecahan terakhir yang terjadi setelah pernyataan bai'at-nya ke Daulah Khilafah Islamiyyah Irak dan Syam pimpinan Abubakar AlBaghdadi adalah panggung terakhir (the last frontier) bagi figur yang sangat dikagumi kalangan pergerakan radikal Indonesia dan sangat disegani oleh para jihadis di berbagai belahan dunia. Pernyataan bai'at ABB ini menyebabkan munculnya perpecahan (firqah) penghujung dari serangkaian perpecahan yang terjadi dalam sejarah panjang pergerakan jihad di Indonesia.

Sejarah pergerakan jihad di Indonesia hampir sama dengan sejarah munculnya kesadaran nasionalisme Indonesia di akhir abad ke-19. Sejarah pada masa awalnya ini adalah sejarah modern kontinuitas (continuity) atau estafeta kepemimpinan jihad di Nusantara. Dimulai dari Hadji Samanhoedi di Surakarta dengan Sarekat Dagang Islam (SDI) pada tahun 1905, dilanjutkan dengan Hadji Mas Tirtoadisoerjo, kemudian dibentuk kesadaran yang lebih politis oleh Hadji Oemar Said atau yang lebih dikenal dengan nama HOS Tjokroaminoto dengan Sarekat 
Islam-nya (SI), berlanjut dengan dibentuknya Partij Sjarikat Islam Indonesia (PSII) dan kemudian Masjoemi (Madjlis Sjoera Muslimin Indonesia). Kontinuitas gerakan modern jihad ini mencapai puncak kesempurnaannya ketika Sekarmadji Maridjan Kartosoewirjo memproklamirkan berdirinya Negara Islam Indonesia (NII) tahun 1949. Sejarah panjang pergerakan Islam pasca SM Kartosoewirjo selanjutnya adalah sejarah perpecahan panjang dan rumit.

Pasca tahun 1962, perkembangan gerakan jihad mengalami titik involusi yang rumit dan melelahkan dari semenjak Abdul Fatah Wirananggapati, secara asinkronik ke Tahmid Rahmad Kartoesoewirjo, kemudian Adjengan Masduki, berliku ke Haji Ismail Pranoto (Hispran), ke Ustadz Abdul Halim atau Abdullah Sungkar hingga kemudian jatuh ke tangan ABB. Pasca 1962, sejarah gerakan jihad ini tidak dapat disebut dengan sejarah kontinuitas, juga tidak dapat disebut diskontinuitas karena masih terus berlangsung dalam proses yang tidak menentu. Sejarah pasca 1962 ini adalah sejarah perubahan (history of change) atau sejarah perpecahan (history of split) gerakan jihad Indonesia yang tidak bisa direkatkan lagi dalam bentuk integrasi. Saya memprediksikan, titik-balik yang akan terjadi setelah ini adalah titik integrasi yang akan berdampak pada seluruh komunitas polity Indonesia. Atau akan munculnya apa yang disebut oleh Clifford Geertz (1972) sebagai revolusi integrasi.

Karl Jackson (1976) menggambarkan bahwa gerakan politik Islam sangat ditentukan oleh pemimpin kharismatik. Faktor figur kepemimpinan yang spiritual, kadang mistik dan bahkan magis menjadi alasan utama bersatunya ummat (Islamic polity) Indonesia di bawah asuhan para ustadz penggerak kesadaran politik yang bahkan menyeruak hingga ke alam modern. SM Kartosoewirjo dalam konteks ini adalah figur kharismatik yang mampu menjadi negarawan. Negara sebagai entitas politik modern diasuh dalam manajemen ilmiah di bawah Imam Kartosoewirjo hingga NII menjadi tonggak penting sejarah politik Islam di Indonesia yang mengubah gaya tradisional ke gaya modern. Adalah Abdullah Sungkar yang kemudian melanjutkan gaya modern ini ke dalam bentuk korporasi jihad yang ultramodern dengan mengadopsi plot dari Al Qaeda di bawah Osamah bin Laden. Plot rencana Al Qaeda 2020 adalah blueprint korporasi politik radikal Islam yang ikut 
mempengaruhi Jamaah Islamiyyah (JI) Indonesia hingga bersublimasi ke gerakan Majelis Mujahidin Indonesia (MMI).

Kepemimpinan kharismatik ABB dibangun mulai dari kasus makar yang dituduhkan Orde Baru terhadap Abdullah Sungkar dan ABB di Jawa Tengah. Para gembong pelanjut Hispran melihat cahaya spiritual bersinar dari sikap konsisten dan konsekuennya dalam mempertahankan kebenaran di tengah otoriterisme Orde baru yang terkenal kejam dan bengis. Kemampuan ABB dalam referensi Islam dan manajemen pergerakan yang berhasil mengirimkan para pengikutnya ke Moro dan Afghanistan telah membuat ABB dianggap sebagai titisan atman ilahi. Kharisma tidak bisa bertahan terlalu lama dalam iklim politik yang terus berubah.

Perpecahan awal pada tahun 1992, ketika lahirnya Jamaah Islamiyyah setelah terbelahnya para jihadis Indonesia yang berjihad dan berhasil ikut serta bersama Thaliban dalam proses futuh (kemenangan) Afghan tahun 1989. Abdullah Sungkar dan ABB memisahkan diri dari Negara Islam Indonesia (NII) atau Darul Islam (DI) dan restart dari entitas awal, Jama'ah Islamiyyah (JI). Sebagamana yang diakui oleh Nasir Abbas, keberangkatannya ke Afghanistan adalah representasi dari NII dan, oleh karenanya, futuh Afghan adalah partisipasi politik kaum jihadis Darul Islam di pentas global. JI kemudian berjalan sendiri karena marasa NII telah dibajak secara ashobiyyah oleh puak tradisional di Jawa Barat. Dalam perkembangan selanjutnya, JI menjadi mitra politik tunggal Al Qaeda di Indonesia, bahkan Asia Tenggara. Terpaan terorisme telah menjadikan JI sebagai organisasi tertutup dan terpaksa menyelam di kedalaman samudra harakah jihad yang tersembunyi. Tertangkapnya beberapa mujahidin dan juga para syahid menjadikan JI mati suri. Pengakuan ABB yang menolak kesaksian Faiz Bafana di persidangan Bom Bali menjadi titik didih perpecahan korporasi jihad JI yang sudah dibangun lama di negeri pengasingan, Malaysia. Korporasi jihad ini kemudian dikayuh oleh Dr Azhari dan Noordin M Top dengan biduk yang berbeda dan bertahan hingga kini dalam situasi yang nanar.

Perpecahan Kedua, semenjak berdirinya Majelis Mujahidin Indonesia (MMI) tahun 2000. MMI adalah organisasi yang mencoba memberikan napas bagi JI yang sudah mati suri di awal millenium ini. ABB terangkat ke permukaan dan muncul secara sangat notorious di dalam sorotan mata dunia. Selama satu dekade berada di 
atas biduk baru yang penuh semilir angin dakwah yang penuh keterbukaan dan reformasi, $\mathrm{ABB}$ tetap konsisten hingga pada suatu waktu ia tidak menyukai sistem politik internal MMI yang dianggapnya mengadopsi sistem Yahudi. Perpecahan pun membasahi pipi para mujahidin yang terpuruk dalam sikap tawadhu' dan hanya berani bertahan dalam perlawanannya terhadap sosok kharismatik ABB.

Perpecahan ketiga, ketika berdirinya Jamaah Ansharut Tauhid tahun 2010. Perpecahan ini membuat komunitas jihad Indonesia hanya tertinggal beberapa gerbong saja. Dengan gerbong yang sedikit, laju JAT semakin dekat ke tujuan sementara: persinggahan di penjara. JAT semakin terjerumus ke lembah radikalisme dan intoleransi yang semakin menjauhkannya dari publik Islam yang sudah mulai begah dengan gaya keras dan mulai mengambil posisi sebagai konstituen partai politik dan sesekali menghirup segarnya udara demokrasi. Situasi yang dialami JAT dari tahun 2010 hingga 2014 ini adalah situasi jihad deadlock yang memperlihatkan disorientasi, dislokasi dan disposisi yang sangat parah bersamaan dengan mendekamnya ABB di penjara Nusa Kambangan. Penjara tidak selamanya merupakan tempat yang bisa memberikan pengaruh simpati pendukung, justru terkadang malah bisa menyebabkan munculnya friksi dan faksionalisme. Apalagi ditemani oleh Aman Abdurrahman yang banyak menyumbangkan ide-ide overradikal paham Wahabi yang kemudian menyebabkan keruntuhan kharisma ABB hingga ke titik nadir.

Perpecahan keempat, ketika munculnya isu ISIS (Islamic State of Iraq and Syam) dan pernyataan sumpah setia ABB kepada figur Abubakar Al-Baghdadi yang mengakibatkan pecahnya JAT dan lahirnya JAS (Jamaah Ansharus Syariah) di bawah pimpinan Ustadz Achwan dan Abu Tholut (Imron Rosyidi). ABB sudah ditinggalkan oleh para pembela setianya, bahkan anaknya pun terpaksa terlontar keluar dan membentuk ikatan baru dari serpihan-serpihan yang terbuang. Perpecahan ini adalah perpecahan terakhir sebuah organisasi jihad di Nusantara yang tidak akan mungkin bisa terpecah lagi setelahnya. Ibarat gelas yang jatuh berkeping-keping, maka perpecahan ini adalah keping terkecil yang jikapun dilempar lagi tidak mampu untuk berpecah lagi (least ability to split). Saya memprediksikan, setelah perpecahan ini akan mengalami suatu titik balik dimana revolusi integrasi adalah sesuatu yang sangat historical inevitability. Keniscayaan sejarah ini tentu 
membutuhkan analisis lebih komprehensif tentang ausnya perpecahan gerakan jihad di Nusantara hingga futuh Indonesia terjadi dan tibanya ajal Pancasila.

Kondisi keruntuhan kepemimpinan kharismatik jihad Indonesia ABB akan merupakan situasi vacuum of leadership yang akan membuka peluang bagi tokohtokoh muda yang sudah lama merajut impian integrasi umat Islam secara politik. Tokoh-tokoh muda radikal Islam di negeri ini tersisa hanya sedikit. Tokoh dengan kemampuan agamis dan manajemen pergerakan modern yang mungkin akan muncul adalah Ustadz Irfan S. Awwas dan Imron Rosyadi (Abu Tholut). Tokoh muda lainnya dianggap tidak memiliki kapasitas keislaman yang memadai meski dengan visi politik yang berlebih. Tokoh mudah radikal Islam Indonesia yang lain umumnya lebih bergelimang dengan asupan demokrasi dan mengepul dalam asap kapitalisme dan liberalisme.

Filsuf Perancis dan sejarawan sosial Michel Foucault (1980) berpendapat bahwa setiap wacana sosial yang melibatkan dihasilkan politik kebenaran klaim bertemu counter-wacana yang menantang legitimasi wacana asli. Kebenaran untuk Foucault sering tampaknya tidak lebih dari hasil perjuangan antara wacana bersaing. Dengan demikian daya menghasilkan atau menciptakan pengertian tentang 'kebenaran'. Hal ini mengingatkan tetapi juga berbeda dari ide bahwa 'mungkin benar', sebuah ide yang mendengarkan kembali ke Plato. Di dalam buku Republik, Thrasymachus berpendapat bahwa gagasan keadilan dalam kepentingan penguasa, yang seringkali tidak adil. Foucault, bagaimanapun, tampaknya hampir tak peduli dengan membuat pertimbangan nilai, setidaknya pada tingkat teoretis, dan lebih peduli untuk hanya menguraikan pandangannya tentang apa yang ada.

Sementara beberapa mempertahankan bahwa ide Foucault kontra-wacana membawa pemikirannya sejalan dengan dialektika Hegelian, Foucault sendiri berpendapat terhadap perbandingan seperti itu. Sementara tesis - antitesis a la Hegelian secara bersamaan muncul dalam kesesuaian dengan teleologi diusulkan di mana Roh Dunia berlangsung melalui sejarah, Foucault menunjukkan bahwa kontra-wacana muncul setelah pelaksanaan wacana. Selain itu, Foucault membayangkan ada, rencana induk grand teleologis berlangsung seperti dalam pemikiran Hegelian. Sebaliknya, perspektif poststructural nya terputus-putus dan sebagian besar terbuka. 
Dalam arti wacana yang paling sederhana adalah percakapan, atau informasi. Untuk Michel Foucault adalah melalui wacana (melalui pengetahuan) bahwa kita diciptakan. Pikirkan cara ini: Jika benar bahwa kita adalah jumlah dari pengalaman kita (pengetahuan yang kita hadapi), maka mereka mengendalikan kehidupan awal kami memiliki kekuatan yang sangat besar. Dalam sebuah keluarga terisolasi, pengetahuan anak tergantung pada hanya beberapa orang. Dalam arti, mereka beberapa orang menciptakan identitas anak. anak tidak bisa tahu apa-apa tapi apa yang dikomunikasikan oleh mereka. Wacana bergabung kekuatan dan pengetahuan, dan kekuatannya berikut dari penerimaan kasual kita tentang "realitas yang kita disajikan". Jika identitas kita diciptakan oleh media, karena semakin, pandangan dunia kita terbatas pada pandangan dunia mereka terisolasi, kaya, individu; kita dibuat untuk berpikir bahwa kita juga harus memiliki mercedes (sehingga membuat mereka dalam kontrol lebih kaya). Wacana dibuat dan diabadikan oleh orang-orang yang memiliki kekuatan dan sarana komunikasi. Mereka yang berada dalam kendali memutuskan siapa kita dengan memutuskan apa yang kita diskusikan. Semua wacana bertindak dengan cara ini. Menurut Foucault, kebenaran, moralitas, dan makna diciptakan melalui wacana. Setiap usia memiliki kelompok dominan unsur diskursif bahwa orang hidup di tidak sadar. Sehingga wacana di kelas kuliah, lebih khusus, pada akhirnya akan ide-ide hak istimewa apa yang normal ( moral "baik" dan "normatif"); dengan menekankan nilai-nilai ini, pendidikan secara implisit akan meminggirkan mereka yang tidak memegang nilai-nilai tersebut. Memvisualisasikan wacana sebagai susunan ide dan konsep di mana dunia dikenal. Jika kita tidak akrab dengan ide, maka kita cenderung menolak gagasan atau konsep dari tangan, karena kita tidak bisa menggunakan pengetahuan masa lalu untuk menghantam konsep itu. Perubahan hanya bisa terjadi ketika elemen kontradiskursif baru mulai menerima perhatian luas melalui sarana komunikasi. Perubahan membutuhkan kepemilikan sarana komunikasi, representasi diri. Wacana tidak pernah benar-benar "murni;" wacana akan selalu mengandung beberapa ukuran elemen kontra-diskursif. Dalam pandangan dunia Foucault tidak ada moralitas mutlak. Moralitas diciptakan melalui penggunaan kekuasaan.*** 


\section{Tujuan, Target, dan Signifikansi Program}

Program counter discourse ini bertujuan (1) untuk memantau dan mengumpulkan data yang akurat dan sebanyak-banyaknya tentang terorisme, radikalisme dan fundamentalisme di Indonesia dan di beberapa tempat lainnya, mendeskripsikan, menganalisis dan menginterpretasikan data tersebut untuk lebih memahami dan gerakan-gerakan, tendensi dan potensi yang mungkin muncul. Program kontra wacana ini juga akan (2) menerbitkan berbagai hasil kajian atau penelitian tentang rujukan-rujukan (referensi) terorisme, radikalisme serta fundamentalisme untuk mendiseminasikan konsep, gagasan dan teori dalam kerangka ilmu pengetahuan dan untuk kebutuhan praktis. Dengan menggunakan metodologi counter-insurgency research dari WF Wertheim dan Christian Snouck Hurgronje, lprogram kontra wacana ini akan (3) berusaha untuk memberikan kontribusi dalam bentuk wacana tandingan, rekomendasi aksi, solusi, model dan metode dalam menangani kasus-kasus terorisme, radikalisme serta fundamentalisme di Indonesia dengan menghadirkan wacana tandingan (contesting discourse). Berbagai wacana tandingan akan disebarkan melalui website (halaman ruang maya dan media sosial), buku dan pamflet.

Program kontra wacana ini menyasar (1) kelompok-kelompok gerakan radikal dan (2) fundamentalis serta (3) kelompok-kelompok teroris yang ada di Indonesia melalui berbagai website dan media sosial (telegram ${ }^{\circledR}$, whatsApp ${ }^{\circledR}$ ) untuk mengimbangi wacana-wacana yang sedang mereka perbincangkan: imamah, daulah, khilafah, jihad, isytisyhad, amaliah jihadiah, bai'at, dll.

Program kontra wacana ini sangat bermanfaat bagi (1) meneguhkan kembali ideologi negara sebagai common-ground yang lebih rasional dan bisa diterima oleh banyak kalangan ketimbang ideologi sektarian dari kelompok-kelompok agama yang parokial; (2) juga menjadi program yang akan mengaktualisasikan kembali sistem demokrasi yang inklusif sebagai alternatif bagi kelompok-kelompok fundamentalis dan radikal yang cenderung suka berkonflik satu sama lainnya bahkan (3) menciptakan konflik internal antara mereka sendiri dengan menghadirkan banyak pemikiran berbagai tokoh yang menjadi rujukan mereka sendiri. Program ini akan menyerupai konsep "wacana/counter-wacana” yang terletak di perbatasan antara sejarah budaya dan kritik sastra yang menggabungkan 
wawasan teoritis dan praktek semiotika, yang mencoba untuk menggambarkan fungsi budaya dari teks-teks suci dan profan. Berfokus pada sejarah negara Perancis selama periode transformasi budaya, sosial, dan politik yang luar biasa, Richard Terdiman (1989: 221) mengkaji bagaimana wacana-borjuis yang dominan novel, koran, dan bentuk media massa lain dari ekspresi-dan upaya intelektual untuk merancang kontra-wacana untuk memeranginya. ${ }^{1}$ Bahkan di masa lalu kontra wacana sudah digunakan sebagai strategi ampuh melawan ideologi yang mulai menggurita di dalam masyarakat.

\section{Metodologi Counter Discourse}

Radikalisme, fundamentalisme dan terorisme selalu mengikuti suatu pola. ${ }^{2}$ Mereka adalah "embattled forms of spirituality," yang muncul sebagai respon terhadap suatu krisis kecurigaan (perceived crisis). Kaum fundamentalis terlibat dalam konflik dengan musuh-musuh sekular yang dicurigai membuat kebijakankebijakan yang bertentangan secara frontal dengan agama. Kaum fundamentalis tidak menganggap pertentangan frontal ini sebagai sebuah "arena bermain" (play ground), melainkan sebuah "medan perang" (battle field) yang serius, yang bukan sekadar sebuah perlawanan politik konvensional, melainkan menganggapnya sebagai sebentuk "perang kosmik" (cosmic war) antara kekuatan-kekuatan yang haq dan kekuatan yang bathil. Mereka takut terhadap —dan selalu merasa adanya ancaman- kaum kafir untuk membasmi mereka yang berasal dari kekuatankekuatan Barat sekular; maka mereka berusaha membentengi diri dengan doktrin dan praktek yang pernah hidup di masa lalu (doktrin dan praktek jihad). Untuk menghindari diri mereka dari "dunia buruk" dan menutup diri dari kontaminasi "perang kosmik" itu, kaum fundamentalis seringkali mundur dan menyempal dari mainstream masyarakat untuk menciptakan budaya tandingan (counter-culture); dan kaum fundamentalis bukanlah kaum yang bermimpi di siang bolong. Mereka menyerap rasionalisme pragmatis dari modernitas, dan, di bawah bimbingan para

\footnotetext{
${ }^{1}$ Richard Terdiman, Discourse/Counter-Discourse: The Theory and Practice of Symbolic Resistance in Nineteenth-Century France, Ithaca: Cornell University Press, 1989.

${ }^{2}$ Martin E. Marty and R. Scott Appleby (eds), Fundamentalisms Observed, Chicago: University of Chicago Press, 1991.
} 
pemimpin kharismatik mereka, menyaring apa yang perlu dari dunia teknikal untuk membuat rencana aksi yang seringkali bersifat destruktif. ${ }^{3}$

Kontra wacana berangkat dari situasi dimana (1) wacana sebagai tesis; dalam pengertian ini kontra wacana akan kemudian hanya menjadi sisi berlawanan dari ide awal. Ini adalah rasa yang lebih tua dari wacana kata. (2) wacana sebagai praktik sosial, cara untuk mewakili dunia, semacam deskripsi cara yang lebih kontemporer menggunakan wacana sesuai penulis di bidang analisis wacana dan analisis wacana kritis (misalnya, Potter dan Wetherell karya awal, Fairclough, van Dijk, dll) Dalam wacana tradisi counter, dipengaruhi oleh Foucault, juga akan menunjukkan sisi yang berlawanan / versi, tapi lebih bernuansa sejauh bahwa banyak curah keluar hubungan antara posisi argumentatif dan mengapa studi mereka adalah yang bersangkutan. Secara khusus mereka mengandaikan bahwa masyarakat adalah terstruktur dengan wacana; itu terdiri 'cara berbicara' (Michael Foucault) yang masuk akal dari hal tetapi sering melakukannya dengan cara yang mendominasi, menindas dan membatasi kemampuan pelaku. Kita tidak bisa tahu di luar bahasa dan kata-kata yang kita dapat (tidak) menggunakan dalam masyarakat kita, setelah semua.

Van Dijk berpendapat bahwa kontra wacana terdiri dari suara tertindas seperti perempuan, imigran dan orang kulit hitam, dimana wacana dominan terdiri dari orang kulit putih elit, yang kedua harus dipelajari dalam rangka untuk memecah "pemeliharaan ketidaksetaraan" ( p.251). Macgilchrist, berikut Laclau \& Mouffe, berpendapat bahwa kontra wacana adalah bagian penting dari upaya terusmenerus untuk membangun pandangan tertentu sebagai dominan, yang kita secara teratur mengalami misalnya, melalui debat pada obat-obatan, jenis kelamin, aborsi, dll. Macgilchrist juga menambahkan bahwa untuk berhasil 'kontra' pandangan 'utama' dari hari kita, kita perlu tahu dalam hal retorika apa yang 'bekerja' dalam hal persuasif, yang merupakan tujuan sosial utama bagi mereka yang terlibat dalam aktivisme, seperti penelitian, amal dan pendidikan.

Jadi dalam sebuah bidang kajian, counter wacana dapat cukup digambarkan sebagai counter-argumen, tapi lebih secara teoritis, sebagai argumen yang terletak

\footnotetext{
3 Jonathan R. White, Terrorism: An Introduction, 1991.
} 
di dalam konteks sosial budaya menangani isu-isu tertentu yang dianggap oleh aktivis sebagai bermasalah. Kita bisa melihat proses ini baik melalui Marxis, lensa feminis atau LGBT ketika kita berpikir tentang bagaimana suara-suara minoritas advokasi hak-hak, pengakuan dan sebagainya dalam waktu mengalahkan argumen 'utama' dan bergoyang opini di dunia barat. Hal yang sama kita melihat pemandangan seperti berjuang untuk bertahan di tempat lain, atau bahkan akan mundur. Ini adalah perjuangan diskursif tersirat dalam banyak teori wacana, perlawanan dan perubahan sosial. Seperti kejadian terungkap, bergeser bolak-balik dapat terjadi dan salah satu dari banyak keindahan bidang besar ini pekerjaan adalah bahwa hal-hal tersebut dapat dilihat sebagai berlangsung lancar; 'Kemajuan' dan konsep pencerahan seperti menjadi bagian dari campuran dan tidak ditinggikan sebagai kebajikan yang saleh. Richard Rorty membuat titik ini dengan menyatakan bahwa argumen sosial yang lebih kondusif untuk memikirkan jika mereka dinilai oleh bagaimana kita memandang hasil dalam waktu saat ini kita hidup di tataran standar abstrak.

Dalam metode yang lebih sederhana, Foucault menyebutkan bahwa "Rules are empty are empty in themselves, violent and unfinalized; they are impersonal and can be bent to any purpose. The successes of history belong to those who are capable of seizing those rules, to replace those who had used them, to disguise themselves so as to pervert them, invert their meaning, and redirect them against those who had initially imposed them; so as to overcome the rulers through their own rules." 4 Wacana bisa digunakan oleh siapapun untuk tujuan apapun untuk menantang sebuah kekuasaan, bahkan sebuah negara, dengan cara membalikkan makna. Maka, makna jihad, daulah, khilafah, bai'at, dan lain-lain bisa saja dimaknai secara lain untuk kepentingan tertentu.

\section{Proses dan Tahapan Program}

Program kontra wacana adalah program yang mencoba menghadirkan wacana tandingan yang dominan atau terlembagakan dengan beberapa wacana

\footnotetext{
${ }^{4}$ Michel Foucault, Language, Counter-Memory, Practice: Selected Essays and Interviews, ed. with a preface by Donald F. Bouchard; trans. Donald F. Bouchard and Sherry Simon (Oxford: Blackwell, 1977), p. 151.
} 
alternatif. Program ini terdiri dari beberapa kegiatan prosesual. Kegiatan tersebut berupa: (1) identifkasi wacana asal, dalam bentuk diskusi tertutup dengan para ahli; (2) menghimpun dan merumuskan interpretasi alternatif; (3) merumuskan wacana baru (counter-discourse) yang akan mampu menghantam wacana yang sudah terlembagakan (institutionalized discourse); (4) membawa wacana tandingan ke domain publik melalui berbagai media (website dan media sosial); (5) mengevaluasi program dan kegiatan.

Program kontra wacana ini akan dikemas dalam berbagai bentuk kegiatan yang tidak kentara sebagai sebuah kegiatan afirmasi politik. Bentuk-bentuk kegiatan tersebut adalah: (1) kegiatan diskusi ahli secara tematik; (2) kegiatan FGD mengidentifikasi wacana dominan yang beredar; (3) diskusi perumusan wacana tandingan; (4) publikasi website; (5) disseminasi melalui media sosial; (6) publikasi buku-buku tematik yang membahas beragam tema radikal, fundamentalis dan teroris; (7) mengelola perang wacana secara ilmiah dengan rujukan bibliografis yang lengkap; (8) menerjemahkan buku-buku klasik karya ulama yang menjadi rujukan; (9) menerjemahkan buku-buku/kitab kontemporer yang menjadi rujukan para pengikut aliran fundamentalisme, radikalisme dan terorisme; (10) mendistribusikan Al Quran; (11) mendistribusikan buku-buku hadist shahih; (12) memberikan beasiswa bagi anak-anak dari keluarga radikal, fundamentalis dan teroris untuk kuliah di jurusan-jurusan yang mengenalkan multikulturalisme.

Kegiatan lainnya dapat dirumuskan dalam bentuk sub-kegiatan atau subprogram yang berdasarkan evaluasi diperkirakan akan perlu dilakukan.

\section{Penutup}

Program kontra wacana ini tidak akan bisa berjalan tanpa dukungan dari berbagai pihak yang mengerti tentang situasi yang dihadapi oleh masyarakat dan pemerintah. Masyarakat menghendaki adanya program nyata untuk memerangi terorisme yang bersifat straight-forward dan bukan sekedar program yang bersifat formalistik apalagi yang legalistik. Terorisme muncul dari penafsiran atas satu wacana yang kemudian dikemas dalam bentuk ideologi oleh gerakan-gerakan sosial politik keagamaan. Cara mereduksinya pun haruslah melalui metode penafsiran yang dihadirkan oleh berbagai kalangan (dengan berbagai rujukan) untuk menghantam ideologi yang dianut oleh gerakan-gerakan sosial politik keagamaan 
tersebut. "There are no relations of power without resistances; the latter are all the more real and effective because they are formed right at the point where relations of power are exercised; resistance to power does not have to come from elsewhere to be real, nor is it inexorably frustrated through being the compatriot of power. It exists all the more by being in the same place as power. ${ }^{5}$ Bahkan bila perlu, budaya tandingan (counter-culture) terhadap ideologi radikal dan fundamentalis tersebut mustilah dihadirkan dalam berbagai bentuk yang mungkin di berbagai domain dan sektor kehidupan.***

\section{Daftar Pustaka}

White, Jonathan R., Terrorism: An Introduction, 1991.

Marty, Martin E. and R. Scott Appleby (eds), Fundamentalisms Observed, Chicago: University of Chicago Press, 1991.

Foucault, Michel. Language, Counter-Memory, Practice: Selected Essays and Interviews, ed. with a preface by Donald F. Bouchard; trans. Donald F. Bouchard and Sherry Simon (Oxford: Blackwell, 1977), p. 151.

Foucault, Michel. Power/Knowledge: Selected Interviews and Other Writings, 19721977, ed. Colin Gordon (Brighton: Harvester, 1980), p. 142.

Terdiman, Richard. Discourse/Counter-Discourse: The Theory and Practice of Symbolic Resistance in Nineteenth-Century France, Ithaca: Cornell University Press, 1989.

${ }^{5}$ Michel Foucault, Power/Knowledge: Selected Interviews and Other Writings, 1972-1977, ed. Colin Gordon (Brighton: Harvester, 1980), p. 142. 